\title{
THE ROLE OF RAILWAY INTEGRATED DISTRIBUTION CENTERS IN INDUSTRIAL ZONES TO IMPROVE LOGISTICS COMPETITIVENESS
}

\author{
Lis Lesmini' ${ }^{1}$, Raden Didiet Rahmat Hidayat ${ }^{2}$, Mohammad Iqbal Firdaus ${ }^{3}$ \\ Johanes Kurniawan Liew ${ }^{4}$ \\ 1. STMT Trisakti, 2. STMT Trisakti, 3. STMT Trisakti, 4. STMT Trisakti \\ corresponding author : lies.1969@yahoo.com
}

\begin{abstract}
To keep competitive price of goods, the cost of logistics goods transport should be low. Shipment of goods in Java Island is dominated by trucks as high as $98 \%$ while the use of trains is only $2 \%$. Truck-based goods transport poses problems from traffic congestion to high fuel inefficiency. Logistics centers integrated with freight railway have become one of the options to solve the the problem. Using qualitative approach, this study aims to investigate how freight railway integrated logistic center improve smooth flow of goods transport. Data collection was obtained through non structured, semi structured and depth interviews. In addition, focus group discussion was also conducted to collect data based on different perspectives from various stakeholders. The result is freight railway in logistics centers if managed properly is capable of lowering lead time, freight costs of goods, and reducing traffic density of highways.
\end{abstract}

Keywords: freight railway, logistics center

\section{Introduction}

The point to point distribution of goods method by trucks which dominate $98 \%$ compared to that of $2 \%$ railway in Java Island is considered to contribute to the inefficiency of logistics costs. One effort to reduce logistics costs is by utilizing railways synergized with ports and roads. Railway is considered to help reduce the density of road and able to transport relatively more goods than point to point style with trucks. The current integrated railway logistics center such as Cikarang Dry Port, Gedebage Dry Port and being built Lookman Djaja Logistics Pak are located in West Java because there are 12 industrial areas in the province with the intense movement of goods through Cikampek toll lanes. This research is intended to see in depth how the the concept of hub and spoke applied in logistics centers integrated with railway is able improve the smooth transportation of goods that leads to the reduction of logistics costs. 
The logistics hub is a large-scale system of logistics providers that work together to provide value-added services by sharing assets. Hubs play an important role in the smooth flow of goods therefore hubs affect the efficiency of goods transport system. Therefore, it is important for a logistics hub to be positioned close to the center where the goods come from and where the goods are flowing so as to form a network (Vieira et al., 2016), so the optimal location of a logistics hub can lower transportation costs and keep price stability of goods through synchronization between production and consumption. In the end, the distribution system of hub and spoke goods will further ensure the distribution of goods and lower costs (Natalia and Agus, 2016).

Intermodal goods transport is an important key to a sustainable overall distribution system of goods (Terrin et al., 2016). So far, transportation of goods by train has been considered as a means of transporting goods with the characteristics of goods transported raw materials in large volumes and not too sensitive by time. Yet, with the right technology and infrastructure, cooperation with other modes of transportation and proximity to warehousing centers and other supporting infrastructure such as roads connected to various industrial centers or warehousing, railway freight will be able to be the main choice in lowering logistics costs (Sinulingga, Surayya and Putri, 2015; Wibowo and Chairuddin, 2017; Vanek and Smith, 2004), Erjavec and Trkman, 2014).

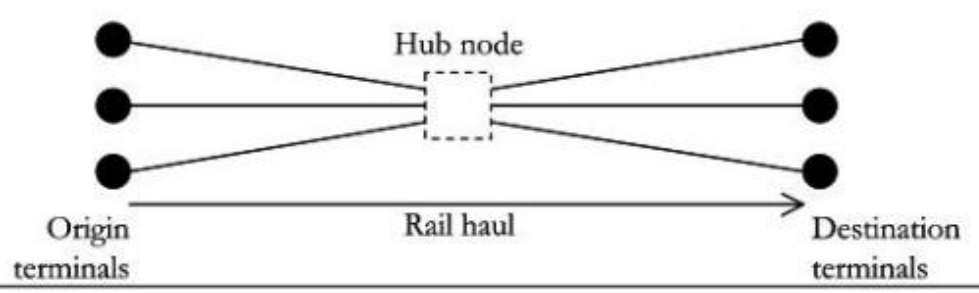

Source: (Bontekoning, 2006)

Figure 1 Hub and Spoke Integrated with railway 


\section{Method}

This study used qualitative approach to depict in depth how integrated railway distribution center improve the smoothness of goods distribution to improve competitiveness. The research was conducted in Cikarang Dry Port and Railway Integrated Logistics Center of Lookman Djaja. Sources of data or research subjects in this study are informants who have the capability and competence so that the information provided credible and in accordance with the needs of this study. We determined that the informants must have the credibility of both hands on logistics practices and academic knowledge who range from the CEOs of a dry port and trucking company, practitioners in freight railway, members of professional association in Logistics and academicians.

Data collection was conducted through structured interview, semi-structured and in-depth interview and focus group discussion. The data analysis techniques used in this study use an approach developed by Miles, Huberman and Saldana (2014) which includes (after data collection) data reduction, separation of data from unfocused, overly detailed and others so that the data will show patterns or themes. Next is to display data that serves to help understand for advanced analysis of an information or event. The last process is the conclusion of the researchers based on the pattern and theme. Withdrawal conclusion is done continuously while data reduction and data display is performed.

\section{Results and Discussion}

\section{Logistics Ceters Integrated with Railway and the Decrease of Logistics}

One of the factors determining the competitiveness of a product is the existence of transport efficiency, which is a concept derived from the inverse ratio between the number of trips with the transport costs. This means that the more trips the vehicle utilization will increase and it will affect the transportation cost. Yet, the more trips the more revenue the vehicle owner gets. 
At present, the ability of trains to compete with other modes of transport in goods delivery, especially trucks is still low due to various factors. The most dominant factors are the high lead time of door to door, the high door to door delivery and limited space for loading and unloading.

This is because the current method of goods transport in Indonesia is still using the concept of point to point compared with the hub and spoke model. The effect of a point to point goods transport system is currently $98 \%$ of freight transport is done by truck and the remaining $2 \%$ by train.
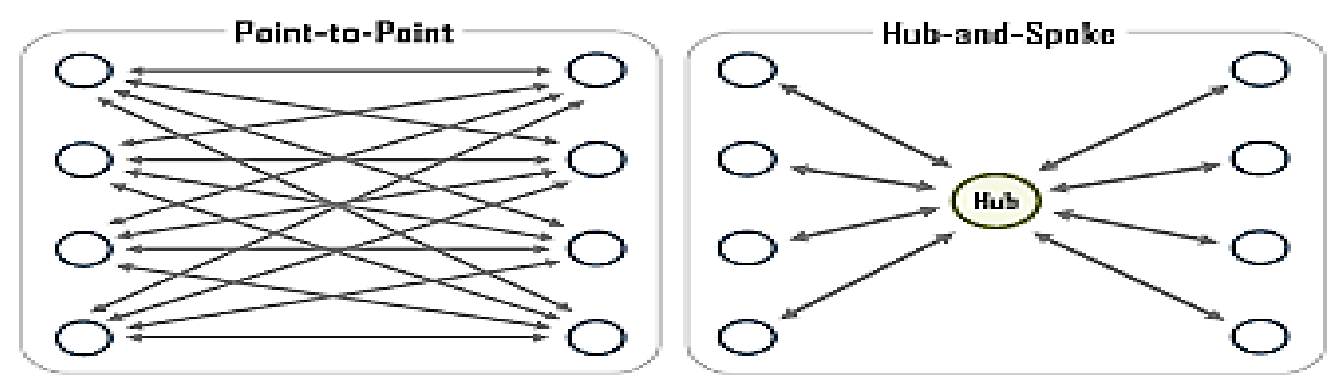

Figure 2. Point-to-point vs Hub and Spoke

In the concept of point to point goods distribution, the transport of goods made from the point of production directly to the destination. The implication is that with many production points and destinations there will be many trips and intersections. The immediate perceived consequence is the occurrence of a bottle neck on the main roads and connections. In Jakarta itself, the congestion due to the high frequency of travel by truck is clearly visible from the density of the Jakarta-Cikampek toll road for almost 24 hours. In addition, trucks also dominate travel on the outer ring toll roads so that congestion also dominates these routes.

The next effect is the low utilization of trucks because the number of trips can not be optimized due to this bottleneck. Truck utilization in Indonesia is only $50.000 \mathrm{~km} /$ year far below of Thailand with 120,000 km/year and European countries where truck utilization reaches $200.000 \mathrm{~km} /$ year. Increased utilization 
will reduce the fixed cost burden as mentioned earlier. To anticipate the low number of trips and maximize the hauling capacity, truck entrepreneurs will increase the carrying capacity beyond the maximum capacity, such as over tonnage or truck with long-chassis. The result is a damaged roads are increasing in number.

On the other hand, the concept of hub and spoke is a distribution model using at least two modes of transport, where the goods are sent from many spokes to one hub and then the goods are moved to a larger mode of transportation in large quantities to be sent from one hub to another. Next, the destination hub will distribute the goods to spokes using smaller modes (ships and trucks, trains and trucks, trucks and vans, vans and motorcycles). The advantages of this type of transport model of goods compared with the concept of point to point are more efficient, cheaper, fuel-efficient, lower carbon emissions, faster and more load transports.

In Java Island, hub and spoke model should have been implemented with trains and trucks because the infrastructure already exists, but this can not run well because there are fewer logistics hubs around the train station. As a result, the production center prefers to ship the goods directly (point to point) with trucks because the total cost is cheaper, the total lead time is faster, and there is no more handling until the destination.

XYZ Jakarta-Surabaya 800 km approx. Rp 6 million

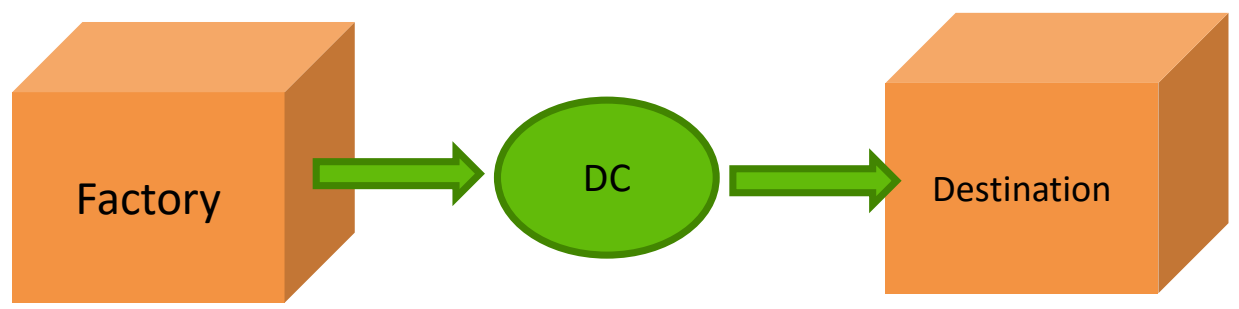

Figure 3. Point to point with truck 


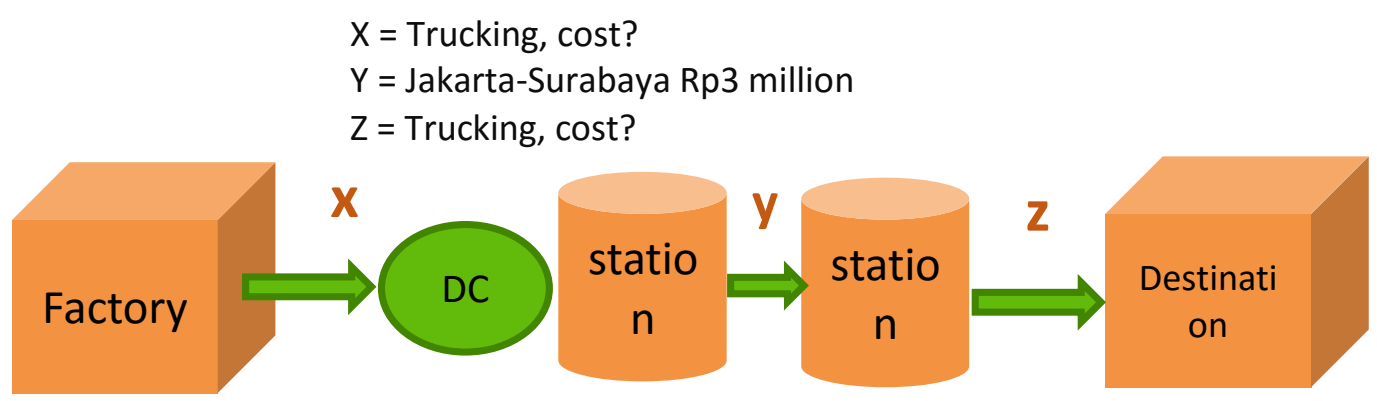

Figure 4. Point to point with railway

Figures 3 and 4 illustrate the delivery of the Jakarta-Surabaya route where $\mathrm{X}$ is the distance between the original warehouse and the station, $\mathrm{Z}$ is the distance of the station to the destination warehouse, and $\mathrm{Y}$ is the distance from station to station. For comparison of total shipping cost through trains and trucks JakartaSurabaya is $\mathrm{X}+\mathrm{Y}+\mathrm{Z}$. For multimodal models of trains and trucks warehouse distance to the station greatly affect the price of transport because the farther $\mathrm{X}$ or $\mathrm{Z}$ then the more expensive the cost.

XYZ < Rp6 million

$\mathrm{XYZ}=$ Jakarta-Surabaya $(800 \mathrm{~km})$

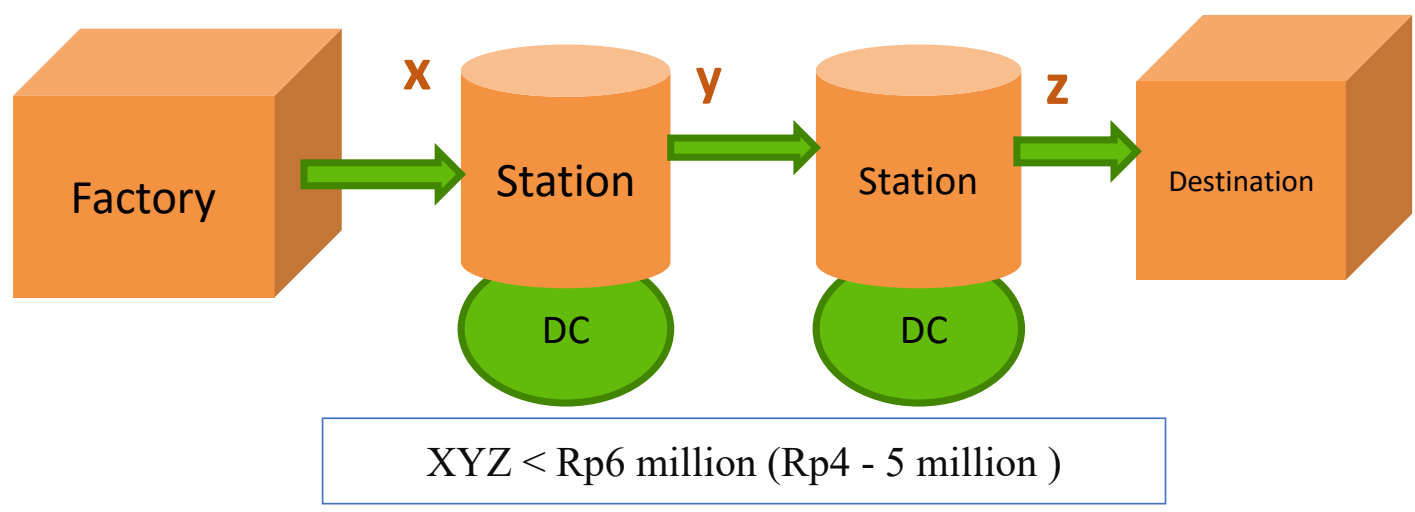

Figure 5. Hub and spoke with logistics center integrated with railway

The solution to the above problem is to create more logistic hubs by approaching the distance $\mathrm{X}$ and distance $\mathrm{Z}$ to the warehouse area. The more hubs there will be 
more trips that can be taken and it affects to the decline of logistics costs such as transportation costs, inventory costs, and makes lead time to be measurable.

\section{Specific Role of Railway Integrated Logistics Center in to Reduce Logistics}

\section{Costs}

With $98 \%$ percent of freight transport dominated by trucks the most immediate immediate implication is how national roads are dominated by large and slowmoving trucks. The result is the congestion that always happens in almost every major segment including toll roads which should be the highway. The decrease in the number of vehicles, especially the freight trucks can reduce the highway density. In addition, the apparent weakness of road-based freight transport is unpredictable lead time. This is due to a variety of factors ranging mainly from the highway density, especially on national holidays where passenger transport is prioritized over the transport of goods. Unpredictable lead time can not provide business certainty that will ultimately reduce the competitiveness of the product or business.

Freight transport, in addition, will be able to shorten lead time significantly. So, the distance between Jakarta and Surabaya which takes 36 hours will be reduced to only 12 hours cutting lead time to almost a third, but the time does not include

the lift on and the lift off. In terms of cost, there is a cost cutting of what should be paid for 36 hours becomes 12 hours only.

This decrease in cost is derived from the depletion of the amount of fuel used by trucks. For example, the volume of cargo served by the Jakarta-Surabaya trains is 12,000 tons or the equivalent of 400 containers. A freight truck from Jakarta to Surabaya requires at least 250 liters of fuel which altogether comes to 100,000 liters of fuel per day in an accumulatively. By using trains, it takes only 14 trains in which each series requires as much as 1,500 liters of fuel, which or 21,000 liters in total. This means $75 \%$ savings on fuel as a whole. 
However, using trains for freight transport does not necessarily make the lead time as the only decisive factor that the owner of the goods will shift the mode of transport from road to rail. Nevertheless, the lead time advantage can be nonlinear with the cost to be paid by the owner of the goods. The first is the loading and unloading costs from warehouse to truck, truck to station, station to truck, truck to destination. It is this component that makes the cost of goods transport by train inefficient, even the difference can reach $30 \%$ difference by truck when compared with conventional rail transport (not yet integrated with logistics centers).

To optimize lead time, or increase the certainty of delivery time while keeping freight costs lower is by increasing the number of stations integrated with industrial zones, optimizing cooperation between freight transport operators and trucking entrepreneurs, as well as optimizing equipment and systems information that can simultaneously synergize their respective roles. The point is that the railway integrated industrial zone acts as a hub as well as spokes in the flow of goods distribution, not only as a transit place for goods transported by train but as a system integrated with other modes of transport in support of the smooth flow of goods from industrial nodes to destination areas.

\section{Current Weaknesses of Freight Transport by Railway}

Currently, railway infrastructure as freight transportation is not sufficient and uneven in distribution. The existing stations are only limited in some industrial centers and have not been integrated optimally because of the various factors of large-scale infrastructure that must be completed. Warehouses or industrial centers based on roads with all existing infrastructure, such as special handling and special storage make the goods owners prefer to use truck mode for the transport and transit their goods.

Among the infrastructure that must be realized is the development of emplacement of goods loading and unloading. This is to accommodate the 
increased flow of goods transit with different types of goods that require different handling as well. Next is the equipment loading and unloading goods that can accommodate various types of goods and integrated with information technology. In addition, the warehousing complex must also be expanded and improved so as to meet the needs of the owners of goods in terms of volume, speed, and handling of the type of goods. In addition other supporting facilities must also be built such as reefer plug for cargo that requires a cooling machine.

These factors contribute to accessibility, flexibility and travel times that are not competitive when compared to other modes of transport, such as by trucks. Accessibility is required for the owner of the goods in order to keep the goods delivered immediately. The construction of new stations close to industrial centers and commercial centers helps keep the flow of goods distribution able to meet demand constantly. If only relying on existing stations then it will be difficult to increase the volume of goods transported due to access that does not become economical for goods originating far from the station.

Flexibility is directly proportional to the addition of special freight railway stations, plus the supporting facilities. With the current infrastructure, the frequency of travel is difficult to add, thereby reducing the flexibility of goods delivery. Time-sensitive items will become irrelevant when transported by train as the owner of the goods can not rely on the limited frequency of current train trips.

All of the above will lead to a high total cost, whereas the attractiveness of freight transport by rail is expected to reduce total costs. If the total cost remains high it will be difficult to raise the level of competitiveness of a particular product due to high logistics costs. 


\section{Conclusion}

The development of logistics distribution center integrated with railway is an effort in order to improve national competitiveness through decreasing logistic cost of goods. The current infrastructure does not support shifting capital from road transport to railway transportation. The existing railway distribution center is able to provide attraction to the owner of goods, especially in terms of speed of travel time but on the other hand it has not been able to attract the owner of goods to use the freight mode of the goods. In order to realize this matter, regulators are required to set up railway transportation a priority of development in order to realize the national logistics system. However, it is not easy to remember the large number of stakeholders involved. The construction of an integrated logistics center with trains that do not have the required equipment in managing transit goods will be difficult to compete with logistics centers that use road transport mode. The costs incurred will be high but if successful then the results obtained will be useful for national logistics competitiveness.

\section{References}

Bontekoning, Y. (2006) Hub exchange operations in intermodal hub-and-spoke operations: comparison of the performances of four types of rail-rail exchange facilities, Thesis Series. Available at: http://books.google.ch/books?id=P9HKC_F9p$8 \mathrm{C} \& \mathrm{dq}=\mathrm{Y} .+$ Bontekoning\&hl=fr\&source $=\mathrm{gbs} \_$navlinks_s.

Erjavec, J. and Trkman, P. (2014) 'The trade-off between road and railroad freight transport - cost benefit analysis for Solvenia', Economic and Business Review, 16(1), pp. 63-76. Available at: http://search.proquest.com.ezp.waldenulibrary.org/abicomplete/docview/1 554604172/fulltextPDF/A85BDB84D53745C8PQ/1 ? accountid=14872.

Miles, M. B., Huberman, A. M. and Saldaña, J. (2014) 'Drawing and Verying Conclusions.', Qualitative Data Analysis A Methods Sourcebook, pp. 275332. doi: 10.1088/1751-8113/44/8/085201.

Natalia, C. and Agus, M. A. (2016) 'Desain Rute Pelayaran Sistem Hub and Spoke ( Studi Kasus: Wilayah Papua, Indonesia )', Jurnal Metris, 17, pp. 113-122.

Sinulingga, T., Surayya, L. and Putri, E. (2015) 'Selecting Transport Modes of Railway and Road Based on Tariff and Travel Time', Jurnal Manajemen 
Transportasi \& Logistik, 2(2), pp. 159-168.

Terrin, J.-J., Table, A., Lulli, G., Pietropaoli, U., Ricciardi, N., Bontekoning, Y., Gatto, M., Jacob, R., Nunkesser, M., Kreutzberger, E., Konings, R., Crainic, T. G., Bektas, T., Okumura, M., Vieira, C. L. dos S., Luna, M. M. M., Gestrelius, S., Boysen, N., Jaehn, F., Pesch, E., Rodrigue, J. P., Notteboom, T., Limbourg, S. and Jourquin, B. (2016) 'A Brief Overview of Intermodal Transportation', Transportation Research Part E: Logistics and Transportation Review. Elsevier Ltd, 45(2), pp. 1-16. doi: 10.1016/j.tre.2008.12.003.

Vanek, F. M. and Smith, R. I. (2004) 'Prospects for rail freight from peripheral regions: The case of North-East Scotland and Grampian Country Foods', International Journal of Logistics Research and Applications: A Leading Journal of Supply Chain Management, 7(1), pp. 59-70. doi: 10.1080/13675560310001619222.

Vieira, C. L. dos S., Luna, M. M. M., Vieira, C. L. dos S. and Luna, M. M. M. (2016) 'MODELS AND METHODS FOR LOGISTICS HUB LOCATION: A REVIEW TOWARDS TRANSPORTATION NETWORKS DESIGN', Pesquisa Operacional. SOBRAPO, 36(2), pp. 375-397. doi: 10.1590/0101-7438.2016.036.02.0375.

Wibowo, W. and Chairuddin, I. (2017) 'Sistem Angkutan Multimoda Dalam Mendukung Efisiensi Biaya Logistik Di Indonesia', Jurnal Manajemen Transportasi Dan Logistik, 4(1), pp. 25-38. 